\title{
SURVIVAL, INDUCTION AND RESUSCITATION OF Vibrio cholerae FROM THE VIABLE BUT NON-CULTURABLE STATE IN THE SOUTHERN CARIBBEAN SEA
}

Milagro FERNÁNDEZ-DELGADO(1,2), María Alexandra GARCÍA-AMADO(2), Monica CONTRERAS(2), Renzo Nino INCANI(3), Humberto CHIRINOS(4), Héctor ROJAS(5) \& Paula SUÁREZ(1)

\begin{abstract}
SUMMARY
The causative agent of cholera, Vibrio cholerae, can enter into a viable but non-culturable (VBNC) state in response to unfavorable conditions. The aim of this study was to evaluate the in situ survival of V. cholerae in an aquatic environment of the Southern Caribbean Sea, and its induction and resuscitation from the VBNC state. V. cholerae non-O1, non-O139 was inoculated into diffusion chambers placed at the Cuare Wildlife Refuge, Venezuela, and monitored for plate, total and viable cells counts. At 119 days of exposure to the environment, the colony count was $<10 \mathrm{CFU} / \mathrm{mL}$ and a portion of the bacterial population entered the VBNC state. Additionally, the viability decreased two orders of magnitude and morphological changes occurred from rod to coccoid cells. Among the aquatic environmental variables, the salinity had negative correlation with the colony counts in the dry season. Resuscitation studies showed significant recovery of cell cultivability with spent media addition $(p<0.05)$. These results suggest that $V$. cholerae can persist in the VBNC state in this Caribbean environment and revert to a cultivable form under favorable conditions. The VBNC state might represent a critical step in cholera transmission in susceptible areas.
\end{abstract}

KEYWORDS: Vibrio cholera; In situ survival; VBNC state; Resuscitation; Aquatic environments; Cholera.

\section{INTRODUCTION}

Vibrio cholerae is one of the most important waterborne pathogens and the causative agent of cholera ${ }^{8}$, a disease of great public health concern in developing countries with low socio-economic status ${ }^{7}$. This microorganism is a natural inhabitant of aquatic environments, which could act as a source and reservoir for human infections ${ }^{8}$. It has been found to survive for extended periods in estuarine and brackish waters and to undergo conversion to a dormancy or viable but non-culturable state $(\mathrm{VBNC})^{8,35}$. This state is a survival strategy adopted by many bacteria when environmental conditions are unsuitable for sustaining normal growth. In this physiological condition bacteria exhibit detectable metabolic function, but are not culturable by conventional laboratory culture methods ${ }^{27}$. It has been shown that VBNC cells are reduced in size and become coccoid ${ }^{6,36}$, and sustain certain functions like metabolic activity, specific gene expression ${ }^{18}$, antibiotic resistance ${ }^{27}$, virulence ${ }^{28}$ and their pathogenic potential for a prolonged time ${ }^{36}$. Environmental conditions are involved in the induction of VBNC state, notably low nutrient concentrations ${ }^{8}$, suboptimal and downshift temperatures ${ }^{3,28}$, elevated salinity, extreme $\mathrm{pH}$ or solar radiation ${ }^{11}$.

Since the concept of the VBNC state was introduced 30 years ago a significant body of research has been done, serving $V$. cholerae as the prototype $^{8}$. Several in vitro induction studies have been carried out in autoclaved water ${ }^{8}$, salt water, buffered saline ${ }^{10}$, alkaline seawater ${ }^{3,18}$, freshwater microcosms ${ }^{25}$ and conditioned medium ${ }^{22}$. Resuscitation of $V$. cholerae from the VBNC state has been demonstrated in the intestines of human volunteers ${ }^{10}$ and recently in vitro by temperature upshift ${ }^{25}$ and co-culture with eukaryotic cells ${ }^{32}$. However, little information is available on the natural behavior of this microorganism, the dynamics of the VBNC state in the environment and the mechanisms whereby non-culturable cells become culturable to initiate seasonal epidemics of cholera, especially from the Caribbean Sea.

Many recent cholera outbreaks have occurred in this part of the world as large outbreaks or as sporadic cases ${ }^{19,30}$. In Venezuela, there have been several epidemics of this disease caused by $V$. cholerae $\mathrm{O} 1$ biotype $\mathrm{El}$ Tor $^{16}$. The pathogen has not been recovered from the environment during interepidemic periods, but instead non-O1, non-O139 strains have been isolated from seawater and planktonic organisms on the Northwestern coast of this country ${ }^{17}$. These serogroups were associated with occasional outbreaks of cholera-like diseases close to the area ${ }^{23}$. Because of the public health importance of the VBNC state and the existing cholera risk in the Caribbean $\mathrm{Sea}^{19}$, the objective of this study was to evaluate the in situ survival of $V$. cholerae by using a diffusion chamber (DC) approach to allow the exposure of the microorganism to the natural conditions of this environment. Moreover, the study aimed to examine in vitro resuscitation procedures to test the recovery of the VBNC cells,

(1) Departamento de Biología de Organismos, Universidad Simón Bolívar, Caracas, Venezuela

(2) Centro de Biofísica y Bioquímica, Laboratorio de Fisiología Gastrointestinal, Instituto Venezolano de Investigaciones Científicas, Altos de Pipe, Edo. Miranda, Venezuela.

(3) Departamento de Parasitología, Universidad de Carabobo, Valencia, Edo. Carabobo, Venezuela.

(4) Asociación de Lancheros de Chichiriviche, Edo. Falcón, Venezuela.

(5) Instituto de Inmunología, Universidad Central de Venezuela, Caracas, Venezuela.

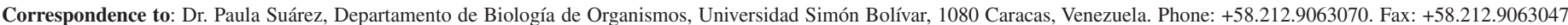
E-mail: psuarez@usb.ve 


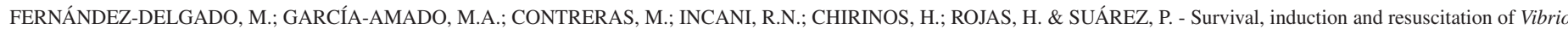
cholerae from the viable but non-culturable state in the Southern Caribbean Sea. Rev. Inst. Med. Trop. Sao Paulo, 57(1): 21-6, 2015.

due to the possibility that the bacterium may resuscitate and start dividing upon access to the host.

\section{MATERIALS AND METHODS}

Bacterial strain and culture conditions: Vibrio cholerae non-O1, non-O139 strain D3-TCBS was obtained from seawater samples collected in December 2004 at Cueva de la Virgen, Cuare Wildlife Refuge $\left(10^{\circ} 54^{\prime} 23^{\prime \prime} \mathrm{N}, 68^{\circ} 18^{\prime} 10^{\prime \prime} \mathrm{W}\right)$, a protected environment also designated as a touristic and shellfish-growing marine area at the Northwestern coast of Falcon State, Venezuela. The strain was cultured according to FERNÁNDEZ-DELGADO et $_{\text {al. }}{ }^{17}$, stocked in nutrient broth (HIMEDIA) supplemented with $15 \%$ glycerol at $-80{ }^{\circ} \mathrm{C}$ and deposited at the Centro Venezolano de Colecciones de Microorganismos (CVCM) (No. 1742).

In situ survival study: Vibrio cholerae D3-TCBS was grown in BHI (HIMEDIA) at $37^{\circ} \mathrm{C}$ in mid-logarithmic growth phase. The cells were harvested by centrifugation at $327 \mathrm{~g}$ for $15 \mathrm{~min}$ at $4{ }^{\circ} \mathrm{C}$ and washed twice with artificial seawater (ASW) $)^{5}$, previously autoclaved at $121{ }^{\circ} \mathrm{C}$ for $15 \mathrm{~min}$ and filtered through a $0.22-\mu \mathrm{m}$ pore-size filter (Millipore). A bacterial suspension in nutrient-free ASW (final concentration $10^{7}$ cells/ $\mathrm{mL}$ ) was aseptically injected into sterile three $\mathrm{mL} \mathrm{DC}$, a modification of those of KAEBERLEIN et al. ${ }^{20}$, and fitted with $0.03-\mu \mathrm{m}$ pore-size polycarbonate membranes (GE Water \& Process Technologies), as described $^{20}$. A number of three DCs filled with ASW without bacterial inoculum were considered as negative controls of the study. Time zero samples were taken for further culturability and microscopic analysis. At the study site, a total of thirty-three chambers were placed vertically in open containers, immersed at approximately one $m$ below the surface in Caño Las Carmelitas $\left(10^{\circ} 55^{\prime} 63^{\prime \prime} \mathrm{N}, 68^{\circ} 17^{\prime} 50^{\prime \prime} \mathrm{W}\right)$ near the sampling site where the study's $V$. cholerae strain was isolated, and exposed to the natural environment for 119 days. During this period, sets of three DCs were sampled at various intervals, kept in containers with the natural seawater under refrigeration and returned to the laboratory to be processed.

The seawater in situ values of $\mathrm{pH}$ (pHep1, Hanna Instruments), salinity (RHS-10ATC refractometer, Westover Scientific), temperature and dissolved oxygen (OXDP-02 oxygen meter, VWR International, Inc.) were monitored throughout the study.

Culturability, cell counting and viability assays: Culturability was determined in triplicates by spread plate count. One milliliter of the material inside the chambers was removed and serial dilutions of suspensions were plated onto BHI agar (HIMEDIA). All the colonies on plates containing fewer than 300 colonies were counted to estimate the colony-forming unit (CFU) per milliliter, after $48 \mathrm{~h}$ of incubation at $37^{\circ} \mathrm{C}$. V. cholerae cells were considered to be in a non-culturable state when counts reached $<10 \mathrm{CFU} / \mathrm{mL}^{1,26}$.

The number of total cells per milliliter was determined by direct microscopic count method using the blue fluorescent dye 4',6-diamidino2-phenylindole (DAPI, Sigma). Aliquots of bacterial suspensions from the chambers were fixed with formaldehyde $(3 \% \mathrm{v} / \mathrm{v})$, diluted in filtersterilized ASW, stained with DAPI $(5.0 \mu \mathrm{g} / \mathrm{mL}$, final concentration) for three min and filtered onto $0.22-\mu \mathrm{m}$ pore-size black polycarbonate filters (Millipore) in the dark. After three rinses in filter-sterilized distilled water, the membrane filter was placed on a slide and a cover slip was placed directly on top of the filter. Additionally, the viability or membrane integrity of bacterial cells was assessed by the LIVE/DEAD BacLight kit (Molecular Probes Inc.). This kit utilizes a mixture of the reagents Syto-9 (a green fluorescent nucleic acid stain) and propidium iodide (PI, a red fluorescent nucleic acid stain). Syto-9 generally labels all bacteria in a population (both cells with intact membranes and damaged membranes). In contrast, PI penetrates only bacteria with damaged membranes and causes a reduction in the Syto-9 stain fluorescence when both dyes are present. Ideally, healthy living bacteria with an intact cytoplasmic membrane stain with a green fluorescence, and dead or injured cells with a compromised membrane stain fluorescent red $^{34}$. These reagents were prepared according to the manufacturer instructions and mixed in equal proportions. A minimum of 15 random fields were visualized for total and viable cell counts under a Nikon TE 2000 fluorescent microscope (Nikon Instrument Inc.). For LIVE/DEAD BacLight stain, a xenon lamp of $100-\mathrm{W}$ was used to deliver light to two filter sets, one set of filters with $485 / 530 \mathrm{~nm}$ of excitation and emission, respectively, and another with $550 / 615 \mathrm{~nm}$ of excitation and emission filters. For DAPI dye a set of 330/450 nm of excitation and emission filters was used. Samples were observed using an oil-immersion objective (100X/0.5-1.3 NA Nikon). All the experiments were carried out in triplicate.

Resuscitation studies: To attempt the recovery of culturability in $V$. cholerae non-O1, non-O139 cells a series of two in vitro approaches were performed when the titer of colony counts in the DC samples declined < $10 \mathrm{CFU} / \mathrm{mL}$. Total cell counts were performed as described previously. To evaluate the effect of nutrients, initial resuscitation assays were performed in 96-well microplates (Corning Incorporated) containing either $50 \mu \mathrm{L}$ $\mathrm{BHI}$ or $50 \mu \mathrm{L}$ HP broth ${ }^{13}$ modified without the addition of antibiotics. The use of HP selective medium originally designed for the isolation of Helicobacter pylori from freshwater samples ${ }^{13}$ allowed the isolation of $V$. cholerae from this aquatic environment ${ }^{17}$. Bacterial cells from three DCs were serially diluted 10 -fold into filter-sterilized ASW $\left(10^{-1}-10^{-7}\right)$ and $50 \mu \mathrm{L}$ samples were taken from undiluted and from each dilution sample and added to twelve replicate wells. A number of two plates were considered for each medium and DC replicate. Wells containing the two media without bacterial inocula and wells with media inoculated with an active growing culture of the same strain (with a known number of total cells and plate counts) were reserved as negative and positive controls, respectively. Plates were incubated at $37^{\circ} \mathrm{C}$, with shaking $(150$ $\mathrm{rpm}$ ) for seven days. Evidence of growth was registered by measuring optical density $(600 \mathrm{~nm})$ of cultures using a microplates reader (Tecan), considering day 0 of the study as the starting point.

Secondly, the effect of spent media (SM, growth media consisting of filter-sterilized culture supernatant) on the recovery of $V$. cholerae cells was investigated. In this study, SM was obtained from $V$. cholerae D3-TCBS cultures harvested at mid-logarithmic and stationary phases and subjected to centrifugation $(327 \mathrm{~g}, 15 \mathrm{~min})$. Cell-free supernatants were filtered twice with disposable syringe filters of $0.22-\mu \mathrm{m}$ pore size (Millipore) and stored at $-80{ }^{\circ} \mathrm{C}$ before use. The wells from plates containing nutrient media and DC samples without evident growth at seven days of incubation were amended with SM, considering one plate for each stage and DC replicate. A number of these wells were left without addition of SM, as controls for spontaneous resuscitation. Other controls of contamination consisted in each stage of SM alone and amended with BHI and HP media. The plates were incubated at $37{ }^{\circ} \mathrm{C}$ with agitation for another seven days. Growth was monitored 


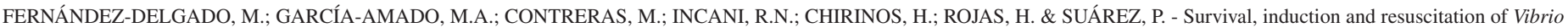
cholerae from the viable but non-culturable state in the Southern Caribbean Sea. Rev. Inst. Med. Trop. Sao Paulo, 57(1): 21-6, 2015.

by measuring the optical density as described previously, including the time zero for this assay.

Statistics: The linear dependence between two variables (Pearson correlation analysis) in the in situ survival study and the effect of nutrients and SM addition on the resuscitation of VBNC cells (Student test of unpaired data) were analyzed by OrigenPRO 7.5 SR6 (Origen Lab Corporation). $p$ values $<0.05$ were considered significant.

\section{RESULTS}

V. cholerae showed declining recoverability on exposure to the aquatic environment and to nutrient depletion conditions. A large population of this microorganism progressively became non-culturable over a period of 119 days when the titer of culturable or colony counts decreased four orders of magnitude (from $2 \times 10^{5}$ to $1 \times 10^{1} \mathrm{CFU} / \mathrm{mL}$ ), and the number of live cells with membrane integrity was $5.2 \times 10^{5}$ cells/mL. Regardless of whether the cells could be grown on agar, they could be seen under the microscope by direct total count within $10^{6}-10^{7}$ cells $/ \mathrm{mL}$. A great difference between colony counts and total cell counts was observed since time zero of the study. Increases in the period of $V$. cholerae exposure to the natural environment (up to 119 days) resulted in a progressive enhancement of non-culturable cells (Fig. 1). From these data, three subpopulations of cells could be inferred at the end of the survival studies: culturable (0.00013\%), VBNC (6.80\%), and nonviable (93.20\%). Morphological changes and decreased size of bacterial cells were observed since the first days of incubation in the natural environment, comprising a large population of coccoid forms. These results indicate physiological changes during the prolonged exposure of $V$. cholerae cells to the aquatic environment which could promote the bacterial survival but decrease the recovery of stressed cells on BHI agar. Preliminary in situ survival studies and microcosm experiments of V. cholerae non-O1, non-O139 in ASW at $17{ }^{\circ} \mathrm{C}$ were performed with similar viability and cultivability results (data not shown).

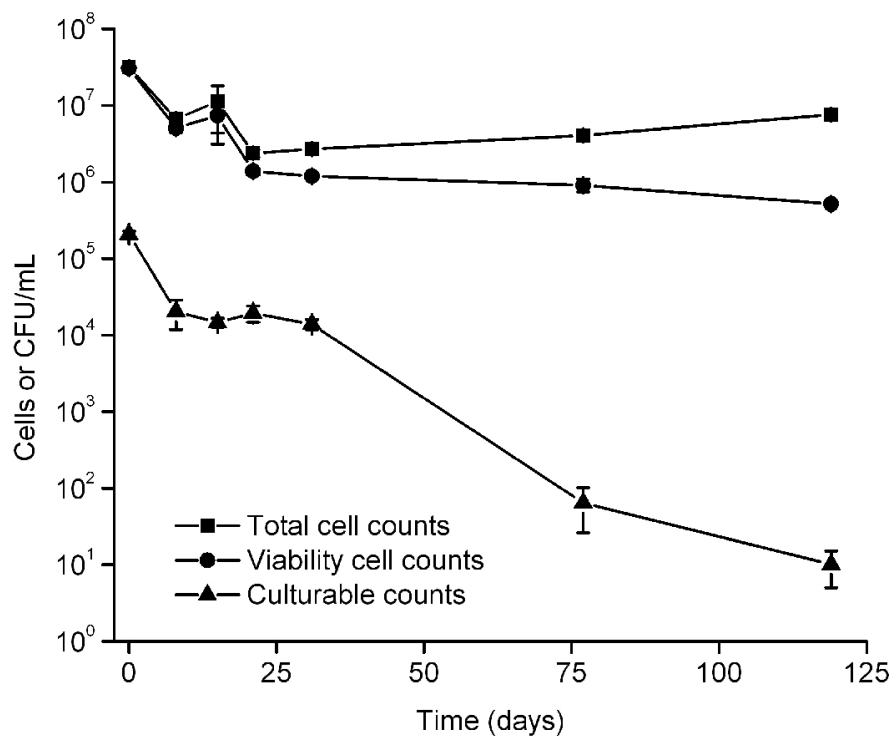

Fig. 1 - In situ survival of Vibrio cholerae on exposure to natural conditions of the Cuare Wildlife Refuge. Data are mean \pm SE values of triplicate samples. Total cell counts $(\boldsymbol{\square})$, viability cell counts $(\boldsymbol{O})$, and culturable counts $(\boldsymbol{\Delta})$.
The environmental parameters: temperature, $\mathrm{pH}$, salinity and dissolved oxygen of seawater registered during the present survival study ranged from $27.2-31.8{ }^{\circ} \mathrm{C}$, $\mathrm{pH}$ 6.5-7, 2-32\%o and 4-7.9 $\mathrm{mg} / \mathrm{L}$, respectively. The most important variation of these seasonal conditions was the salinity of seawater, which was found with two distinct patterns during the rainy (from 0 to 21 days) and dry periods (from 21 to 119 days) considered in this study. When salinity was between two and $18 \%$, the culturability of $V$. cholerae was higher than $1 \times 10^{4} \mathrm{CFU} / \mathrm{mL}$, whereas salinities higher than $18 \%$ o produced cultivability of up to three orders of magnitude fewer (Fig. 2).

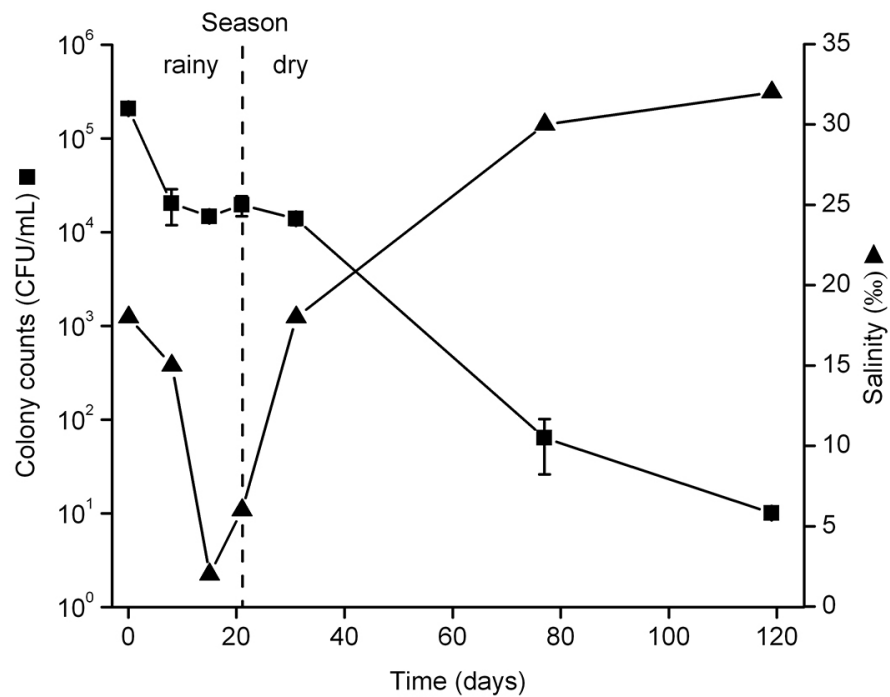

Fig. 2 - Culturability of Vibrio cholerae cells associated with seawater salinity during sampling time. The broken line distinguishes the two seasons: rainy (from 0 to 21 days) and dry (from 21 to 119 days). Data are mean \pm SE values of triplicate samples. Colony counts

(ם) and salinity $(\mathbf{A})$.

There was no significant correlation between the colony counts and salinity for the first 21 days $(r=0.704 ; p=0.295)$, while a significant inverse correlation was found for the second period of the study after day 21 until day 119 ( $r=-0.980 ; p=0.019)$. The reduced levels of salinity registered in the first month of this study coincided with the local rainy season which increases the drainage of adjacent freshwater bodies and may modify the physicochemical conditions of this coastal area.

Results from resuscitation experiments initially showed regrowth of $V$. cholerae non-culturable cells in the undiluted samples by the addition of $\mathrm{BHI}$ and HP media. However, after serial dilutions no growth was evident with both media. The addition of SM at logarithmic and stationary phases to those wells containing $10^{-2}$ diluted samples, previously supplemented with either HP or BHI, showed the recovery of non-culturable cells and was found to be significant $(p<0.05)$ (Fig. 3).

\section{DISCUSSION}

Cholera is a disease of great public health concern in developing countries and has recently re-emerged in a Caribbean coastal area with severe outbreaks or sporadic cases. The reasons of the unusual dynamic of cholerae outbreaks and the status regarding the $V$. cholerae population in this region are not completely clear ${ }^{19,30}$. Although the ecology of $V$. cholerae in marine and estuarine ecosystems as well as its viability in laboratory microcosms has been well studied ${ }^{8}$, only one 


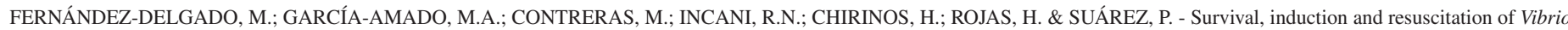
cholerae from the viable but non-culturable state in the Southern Caribbean Sea. Rev. Inst. Med. Trop. Sao Paulo, 57(1): 21-6, 2015.

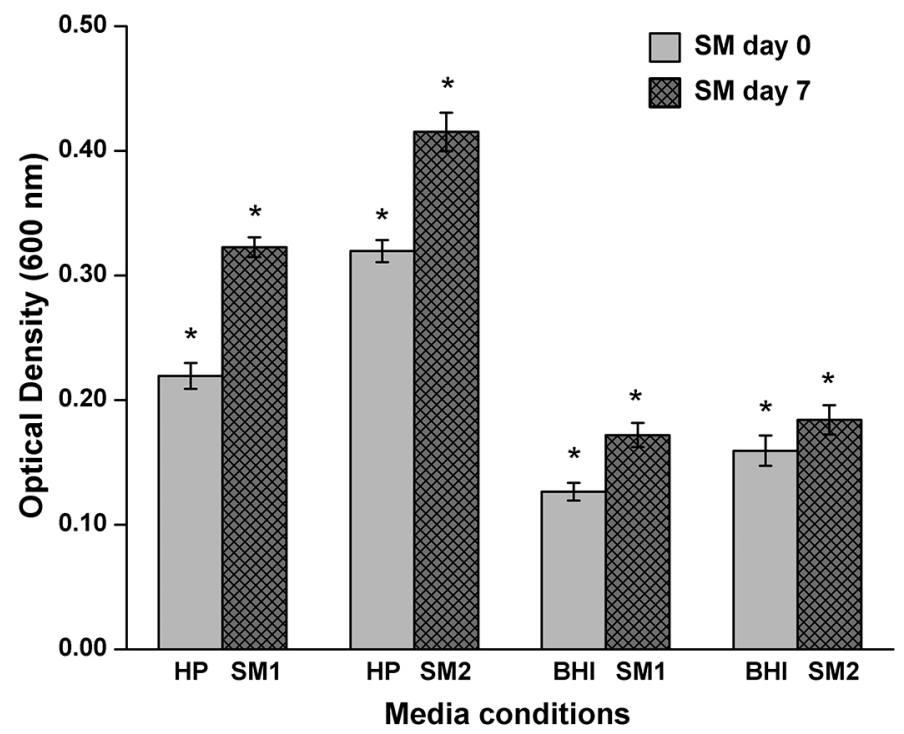

Fig. 3 - Resuscitation of Vibrio cholerae cells from the VBNC state by adding spent media (SM) at logarithmic (SM1) and stationary (SM2) phases in samples diluted $10^{-2}$. SM day 0 (巨) and SM day 7 (网). Data are mean \pm SE of a minimum of 23 and a maximum of 36 replicate values. The symbol * shows significant effect $(p<0.05)$ for paired data of SM addition on the resuscitation of VBNC cells.

piece of research has reported the in situ survival of this microorganism in aquatic environments ${ }^{29}$. However, several studies have employed diffusion chamber approaches to assess the VBNC state in other Vibrio and bacterial species ${ }^{27}$. The present work reveals, for the first time, the capacity of $V$. cholerae to enter the VBNC state when exposed to the real conditions of a coastal area of the Southern Caribbean Sea where this bacterium was isolated, in order to better understand its behavior in this environment as a potential natural reservoir. $V$. cholerae non-O1, non-O139 survived for extended periods of time (approximately four months), demonstrating a decrease in culturability and viability, as has been reported for this species ${ }^{10}$. The bacterial cells reduced their size and changed their morphology from rods to coccoid. This is in agreement with the description of the V. cholerae coccoid morphology in the VBNC state as an adaptation of the cells to environmental constraints ${ }^{6,22,25}$. The entrance of $V$. cholerae to this state was probably mainly induced by the exposure to the constant nutrient depletion conditions inside the chambers during the study. Starvation has been recognized as an important stimulus to enter the VBNC state and represents a common strategy for survival among bacteria in nutrient-poor environments ${ }^{8}$. Moreover, the study found a starvation response of $V$. cholerae in combination with high salinity values of seawater during the dry season (after day 21 to 119) that caused a decrease on the cell culturability with a significant inverse correlation, although in the first 21 days the colony counts were not affected by the salinity decline during the rainy season. Prior to the authors' research, many surveys were conducted on the Northwestern coast of Venezuela in search of culturable forms of $V$. cholerae, and only non-O1, non-O139 strains were recovered during an intense rainy season with low salinity waters ${ }^{17}$. Similar reduced levels of salinity registered in the bacterial cultivability period of this research, occurred during the local rainy season; such low salinity has been widely reported as optimal (between 5\%o and 25\%o) for this microorganism in aquatic environments ${ }^{24}$. Uncovering the influence of rainfall and salinity fluctuations on $V$. cholerae recoverability from these marine environments might be important in understanding the local environmental drivers of cholera outbreaks in the Caribbean region.

The role of the VBNC state in cholera epidemiology is vital, not just because the bacterium can persist in harsh environmental conditions, but also because of its potential to revert back to a fully potent pathogenic form and contribute to the spread of the disease ${ }^{25}$, as has been shown with other Vibrio spp. in mouse models where non-culturable cells remained virulent and were capable of causing fatal infections following in vivo resuscitation ${ }^{28}$. Therefore, it is important to define the mechanisms by which non-culturable cells return to culturability ${ }^{2}$. Resuscitation studies reported here show recovery of cell cultivability when SM at logarithmic and stationary phases were used along with $10^{-2}$ diluted cells, whereas nutrient addition did not show true resuscitation suggesting the presence of culturable cells in the undiluted samples. It has often been questioned whether resuscitation of apparently non-culturable cells represents 'true' resuscitation of all cells of the initial inoculum that had become VBNC, regrowth of only a few non-culturable cells remaining viable (able to revert to active growth), or merely growth of a very few culturable cells ${ }^{5,25,27}$. In the present study, the resuscitation of non-culturable cells was attempted after dilution with several resuscitation procedures, along with different enrichment media and SM addition. A previous step of either HP or BHI addition did not increase the recovery of $V$. cholerae cells in the diluted samples. However, significant growth at $10^{-2}$ dilution was observed after the addition of SM at logarithmic and stationary phases. The culture supernatants could contain components that apparently aided in the recovery of a number of non-culturable $V$. cholerae cells. These findings are likely related to observations of other authors who report an increase in the recovery of bacteria after adding cell-free supernatants from active cultures, whose results indicate that intercellular communication or growthpromoting factors are likely to improve their culturability $4,21,31,33$.

The observations of the present study's authors suggest that a fraction of the cell population is able to recover culturability. A physiological heterogeneity could exist within this $V$. cholerae population, as has been reported with $V$. cholerae $\mathrm{O} 1$ cells resuscitated by temperature upshift ${ }^{24}$ and with other Vibrio species ${ }^{12}$. Recently, EPSTEIN ${ }^{14}$ described this heterogeneity as a percentage of cells that are different from the rest of the population due to the lack of growth restrictions typical of the majority, and proposed a signaling scout model to explain the cell heterogeneity ${ }^{14}$. In this model, a few viable cells or scouts have a signaling function in the dormant population and may start a new population by waking up the dormant cells ${ }^{15}$. Considering this principle, the resuscitation of $V$. cholerae presumably occurred in those diluted samples that had scouts or possible growth-inducing factors. These in vitro resuscitation studies could mimic what happens with non-culturable $V$. cholerae strains during times of stress or interepidemic periods if eventually the presence of favorable environmental conditions or the availability of nutrients and the appearance of signaling cells, enhance their recovery from the VBNC state in these aquatic environments. More work is required to study the resuscitation of VBNC cells and the compounds possibly present in these culture supernatants.

In conclusion, these results emphasize the need to study nonculturable $V$. cholerae in areas of the Caribbean Sea susceptible to cholera epidemics, considering that this bacterium can persist in the environment in a VBNC state and revert to a transmissible form in the presence of suitable conditions. Because the VBNC state might represent 
FERNÁNDEZ-DELGADO, M.; GARCÍA-AMADO, M.A.; CONTRERAS, M.; INCANI, R.N.; CHIRINOS, H.; ROJAS, H. \& SUÁREZ, P. - Survival, induction and resuscitation of Vibrio cholerae from the viable but non-culturable state in the Southern Caribbean Sea. Rev. Inst. Med. Trop. Sao Paulo, 57(1): 21-6, 2015.

a critical step in cholera transmission around the world and particularly in the Caribbean and Latin American region, this research encourages investigators, governments and communities involved in public health to implement and not neglect the programs for prevention, systematic environmental monitoring and surveillance of culturable and VBNC $V$. cholerae through the global networks.

\section{RESUMEN}

\section{Supervivencia, inducción y resucitación de Vibrio cholerae del estado viable no cultivable en el sur del Mar Caribe}

El agente causal del cólera, Vibrio cholerae, puede entrar a un estado viable no cultivable (VNC) en respuesta a condiciones desfavorables. El objetivo de este estudio fue evaluar la supervivencia in situ de $V$. cholerae en un ambiente acuático al sur del Mar Caribe y su inducción y resucitación del estado VBNC. V. cholerae no-O1, no-O139 fue inoculado en cámaras de difusión ubicadas en el Refugio de Fauna Cuare, Venezuela, y monitoreado para contaje de colonias, células totales y viables. En 119 días de exposición al ambiente, el contaje de colonias fue $<10 \mathrm{UFC} / \mathrm{mL}$ y una fracción de la población bacteriana entró al estado VBNC. Adicionalmente, la viabilidad disminuyó dos órdenes de magnitud y ocurrieron cambios morfológicos de células bacilares a cocoides. Entre las variables del ambiente acuático, la salinidad presentó correlación negativa con el contaje de colonias. Los estudios de resucitación mostraron recuperación significativa de la cultivabilidad celular con adición de sobrenadantes de cultivos en crecimiento activo $(p<0.05)$. Estos resultados sugieren que $V$. cholerae puede persistir en estado VBNC en este ambiente de Caribe y revertir a una forma cultivable bajo condiciones favorables. El estado VBNC podría representar un paso crítico en la transmisión del cólera en áreas susceptibles.

\section{ACKNOWLEDGEMENTS}

This work was partially funded by grants from Decanato de Investigación y Desarrollo (DID) to P.S. and Decanato de Postgrado to M.F. of Universidad Simón Bolívar, and grants from the Instituto Venezolano de Investigaciones Científicas to M.A.G. and M.C. The authors gratefully acknowledge S. Epstein for his valuable advice on scientific aspects of the project and supplies facilities, and also to reviewers of this manuscript for their useful suggestions.

\section{AUTHOR CONTRIBUTIONS}

M. Fernández-Delgado: Sampling, experimental procedures, results analysis and manuscript preparation. M. A. García-Amado: Results analysis. M. Contreras: Results analysis. R. N. Incani: Sampling, laboratory support and manuscript preparation. H. Chirinos: Sampling. H. Rojas: Microscopic and statistical analysis, and manuscript preparation. P. Suárez: Sampling, results analysis and manuscript preparation.

\section{REFERENCES}

1. Adams BL, Bates TC, Oliver JD. Survival of Helicobacter pylori in a natural freshwater environment. Appl Environ Microbiol. 2003;69:7462-6.

2. Alam M, Sultana M, Nair GB, Siddique AK, Hasan NA, Sack RB, et al. Viable but nonculturable Vibrio cholerae $\mathrm{O} 1$ in biofilms in the aquatic environment and their role in cholera transmission. Proc Natl Acad Sci USA. 2007;104:17801-6.
3. Asakura H, Ishiwa A, Arakawa E, Makino S, Okada Y, Yamamoto S, et al. Gene expression profile of Vibrio cholerae in the cold stress-induced viable but nonculturable state. Environ Microbiol. 2007;9:869-79.

4. Bjergbæk LA, Roslev P. Formation of nonculturable Escherichia coli in drinking water. J Appl Microbiol. 2005;99:1090-8.

5. Bogosian G, Aardema ND, Bourneuf EV, Morris PJL, O'Neil JP. Recovery of hydrogen peroxide-sensitive culturable cells of Vibrio vulnificus gives the appearance of resuscitation from a viable but nonculturable state. J Bacteriol. 2000;182:5070-5.

6. Chaiyanan S, Chaiyanan S, Grim C, Maugel T, Huq A, Colwell R. Ultrastructure of coccoid viable but non-culturable Vibrio cholerae. Environ Microbiol. 2007;9:393402 .

7. Charles RC, Ryan ET. Cholera in the $21^{\text {st }}$ century. Curr Opin Infect Dis. 2011;24:4727.

8. Colwell RR. Viable but non cultivable bacteria. In: Epstein SS, editor. Uncultivated Microorganisms. Berlin: Springer Verlag; 2009. p. 121-9.

9. Colwell RR, Brayton PR, Grimes DJ, Roszak DR, Huq SA, Palmer LM. Viable but nonculturable Vibrio cholerae and related pathogens in the environment: implications for release of genetically engineered microorganisms. Bio/Technology. 1985;3:81720 .

10. Colwell RR, Brayton P, Herrington D, Tall B, Huq A, Levine MM. Viable but nonculturable Vibrio cholerae $\mathrm{O} 1$ revert to a cultivable state in the human intestine. World J Microbiol Biotechnol. 1996;12:28-31.

11. Colwell RR, Huq A. Vibrios in the environment: viable but non culturable Vibrio cholerae. In: Wachsmuth K, Blake PA, Olsvik R, editors. Vibrio cholerae and cholera: molecular to global perspective. Washington: American Society for Microbiology; 1994. p. $117-33$

12. Coutard F, Crassous P, Droguet M, Gobin E, Colwell RR, Pommepuy M, et al. Recovery in culture of viable but nonculturable Vibrio parahaemolyticus: regrowth or resuscitation? ISME J. 2007;1:111-20.

13. Degnan AJ, Sonzogni WC, Standridge JH. Development of a plating medium for selection of Helicobacter pylori from water samples. Appl Environ Microbiol. 2003;69:2914-8.

14. Epstein SS. General model of microbial uncultivability. In: Epstein SS, editor. Uncultivated microorganisms. Berlin: Springer Verlag; 2009a. p. 131-59.

15. Epstein SS. Microbial awakenings. Nature. 2009b;457:1083.

16. Fernández S, Toro E, Quintero W, Vargas J, Blanco J, Spadola E, et al. Vibrio cholerae O1 en Venezuela 1997-1999, sensibilidad a los antibióticos. Rev Inst Nac Hig. 2002;33:25-30.

17. Fernández-Delgado M, García-Amado MA, Contreras M, Edgcomb V, Vitelli J, Gueneau $\mathrm{P}$, et al. Vibrio cholerae non-O1, non-O139 associated with seawater and plankton from coastal marine areas of the Caribbean Sea. Int J Env Health Res. 2009;19:279-89

18. González-Escalona N, Fey A, Höfle MG, Espejo RT, Guzmán CA. Quantitative reverse transcription polymerase chain reaction analysis of Vibrio cholerae cells entering the viable but non-culturable state and starvation in response to cold shock. Environ Microbiol. 2006;8:658-66.

19. Jenson D, Szabo V, Duke FHI, Haiti Humanities Laboratory Student Research Team. Cholera in Haiti and other Caribbean regions, $19^{\text {th }}$ century. Emerg Infect Dis. $2011 ; 17: 2130-5$

20. Kaeberlein T, Lewis K, Epstein SS. Isolating "uncultivable" microorganisms in pure culture in a simulated natural environment. Science. 2002;296:1127-9. 
FERNÁNDEZ-DELGADO, M.; GARCÍA-AMADO, M.A.; CONTRERAS, M.; INCANI, R.N.; CHIRINOS, H.; ROJAS, H. \& SUÁREZ, P. - Survival, induction and resuscitation of Vibrio cholerae from the viable but non-culturable state in the Southern Caribbean Sea. Rev. Inst. Med. Trop. Sao Paulo, 57(1): 21-6, 2015.

21. Kaprelyants AS, Mukamolova GV, Kell DB. Estimation of dormant Micrococcus luteus cells by penicillin lysis and by resuscitation in cell-free spent culture medium at high dilution. FEMS Microbiol Lett. 1994;115:347-52.

22. Krebs SJ, Taylor RK. Nutrient dependent, rapid transition of Vibrio cholerae to coccoid morphology and expression of the toxin co-regulated pilus in this form. Microbiology. 2011;157:2942-53.

23. Levy A, Salazar J, Mata M, Sandrea L, Paz A, Valero K, et al. Bacterias enteropatógenas en la comunidad étnica Añu de la Laguna de Sinamaica, Estado Zulia, Venezuela. Rev Soc Venez Microbiol. 2009;29:84-90.

24. Lipp EK, Huq A, Colwell RR. Effects of global climate on infectious disease: the cholera model. Clin Microbiol Rev. 2002;15:757-70.

25. Mishra A, Taneja N, Sharma M. Viability kinetics, induction, resuscitation and quantitative real-time polymerase chain reaction analyses of viable but nonculturable Vibrio cholerae $\mathrm{O} 1$ in freshwater microcosm. J Appl Microbiol. 2012;112:945-53.

26. Nowakowska J, Oliver J. Resistance to environmental stresses by Vibrio vulnificus in the viable but nonculturable state. FEMS Microbiol Ecol. 2013;84:213-22.

27. Oliver JD. Recent findings on the viable but nonculturable state in pathogenic bacteria. FEMS Microbiol Rev. 2010;34:415-25.

28. Oliver JD, Bockian R. In vivo resuscitation, and virulence towards mice, of viable but nonculturable cells of Vibrio vulnificus. Appl Environ Microbiol. 1995;61:2620-3.

29. Pérez-Rosas N, Hazen TC. In situ survival of Vibrio cholerae and Escherichia coli in tropical coral reefs. Appl Environ Microbiol. 1988;54:1-9.
30. Piarroux R, Barrais R, Faucher B, Haus R, Piarroux M, Gaudart J, et al. Understanding the cholera epidemic, Haiti. Emerg Infect Dis. 2011;17:1161-8.

31. Pinto D, Almeida V, Almeida Santos M, Chambel L. Resuscitation of Escherichia coli $\mathrm{VBNC}$ cells depends on a variety of environmental or chemical stimuli. J Appl Microbiol. 2011;110:1601-11.

32. Senoh M, Ghosh-Banerjee J, Ramamurthy T, Hamabata T, Kurakawa T, Takeda M, et al. Conversion of viable but nonculturable Vibrio cholerae to the culturable state by co-culture with eukaryotic cells. Mibrobiol Immunol. 2010;54:502-7.

33. Sun ZH, Zhang Y. Spent culture supernatant of Mycobacterium tuberculosis H37Ra improves viability of aged cultures of this strain and allows small inocula to initiate growth. J Bacteriol. 1999;181:7626-8.

34. Terzieva S, Donnelly J, Ulevicius V, Grinshpun SA, Willeke K, Stelma GN, et al Comparison of methods for detection and enumeration of airborne microorganisms collected by liquid impingement. Appl Environ Microbiol. 1996;62:2264-72.

35. Xu HS, Roberts N, Singlenton FL, Attwell RW, Grimes DJ, Colwell RR. Survival and viability of nonculturable Escherichia coli and Vibrio cholerae in the estuarine and marine environment. Microb Ecol. 1982;8:313-23.

36. Zhong L, Chen J, Zhang X-H, Jiang Y-A. Entry of Vibrio cincinnatiensis into viable but nonculturable state and its resuscitation. Lett Appl Microbiol. 2007;48:247-52.

Received: 15 April 2013

Accepted: 28 May 2014 